\title{
COOPERATION WITH ZIMBABWE
}

\author{
Anne WALRAET \\ Third World Seminar (RUG) \\ Universiteitsstraat 4 \\ 9000 Gent
}

Following last year's decision by the Belgian Ministry of Development Cooperation to streamline all bilateral aid programmes to the countries of Southern Africa in order to take account of the new regional emphasis, it makes sense now to reflect on cooperation with Zimbabwe in the context of cooperation with the SADCC. The above decision was preceeded by the allocation of a regional budget of BEF 600 million for SADCC projects and is accompanied by the setting up in Harare of a field office serving as headquarters for the whole region (except Tanzania). All these innovations must be welcomed; they imply the recognition of the SADCC and are congruent with the recommendations of a joint study by the SADCC and the OECD Development Centre, dating back to 1987.

There are however some points that need further explanation... First of all, it remains uncertain whether the announced streamlining of the bilateral aid programmes will be accompanied by a merging of bilateral funds into the regional budget. Indeed, if the announced regional budget of 600 million BF should replace the current bilateral budget, or imply a drastic decrease in the level of bilateral aid, then the SADCC region would not be gaining that much in financial terms. This would be particularly alarming since the level of Belgian support for the SADCC countries has turned out to be very modest.

A linked issue of concern is the long delays between the programming of aid and actual implementation. In extreme cases, aid promised or planr"d is never executed. This is particularly true for Zimbabwe. The initial Belgian pledges at the ZIMCORD 
Conference in 1981 were nevertheless very promising. Yet, after nine years of development cooperation with Zimbabwe, the amount of direct Belgian aid - that part of aid for which the Ministry of Development Cooperation is the sole originator (in contrast to indirect aid, in which NGO's play a decisive role) - stands at the disappointing level of BEF 112 million; BEF 12,5 million on annual basis, or US \$ 360.000. The same applies to the SADCC region as a whole. In this case, the difference between programmed and actual aid transfers amounts to 100 million $\mathrm{BF}$ per year (not even including the programmed 600 million BF). BEF 100 million indeed makes a significant difference since the actual aid on annual basis to the nine countries of Southern Africa stands at the meagre level of approx. BF 330 million. This is not persuasive evidence of a Belgian policy strongly in favour of the SADCC.

My major point of concern, however, is the extent to which Belgium, and other donors, will be prepared to go along with the SADCC's aim of developing the productive sectors of the economy. The SADCC has set towards the goal of increasing its productive capacity and diversifying its economies, in a regional integrated manner. This is a challenging objective both for the SADCC states themselves and for the donor community.

Especially critical for the SADCC governments themselves will be an agreement on an industrial priority and location plan with an associated intra-regional trade system, which could provide a framework for channelling the activities of their own national institutions and those of aid institutions, foreign private investors and not at least Transnational Corporations.

Inherent in this debate is the concern of the SADCC about the dominance of Zimbabwe. More precisely, will Zimbabwe consider the costs of allocating industries according to equilibrium criteria (such as the loss of foreign investment) to be too high. More challenges will have to be faced when a politically acceptable South Africa enables cooperation with the SADCC states within or outside the SADCC framework.

It is logical that, within the objective of developing the region's institutional and productive capacity, the SADCC has urged its donors to make better use of regional experts, contractors and suppliers in the execution of the projects, be they in the transport and communications, energy, agricultural or industrial sector. This is a major challenge to the donors. As is the case with the majority of the donors, Belgian aid is tied to the procurement of goods and linked services. The commercial benefits for the Belgian economy have gained importance as factors affecting the decisions on aid proposals, particularly in the years of recession. Yet in many cases the result is counterproductive as it frustrates local productive and manpower capacity. The maintenance of the $100 \%$ tied aid formula is therefore incompatible with praising 
the efforts of the SADCC states to develop their own productive and manpower capacities.

A move in the right direction could be to open up tenders for local producers. The global EC provision to allow procurement of aid goods or components within the recipient country or region can serve as a model. A more modest alternative could be to allow a certain percentage of the aid package to be supplied by local producers.

Better use of local component production potential would contribute to the aim of standardizing spare parts and decreasing dependence on foreing imports which need to be paid for in scarce hard currency.

A clearly defined industrial strategy would of course help to avoid counter-productive aid.

In the light of the shift in emphasis by the SADCC from infrastructural to productive sector development, requests to donors have been expanded by calls to local and foreign private enterprises. Underlying this development is an acceptance of the need for private foreign capital; aid will not continue indefinitely and low commodity prices and deteriorated terms of trade make it impossible to generate investable surpluses. The present situation, however, represents a dramatic fall in the flow of non-concessional resources from the OECD countries to the SADCC region. Moreover, the rapid reduction in private foreign involvement has not been compensated by a similar increase in official assistance.

After a successful campaign of promoting 'regional thinking' at government level, the SADCC is now working on persuading the enterprise sector. The role of the foreign enterprise sector, as envisaged by the SADCC, is to enter into joint-ventures with local partners. Joint-ventures are not seen solely as a mechanism for securing investment capital, but also as a vehicle for promoting the transfer of technology and know-how to the region. Donors are explicitely asked to support this aim with their aid funds, particularly by funding the newly established Export Pre-Financing Revolving Funds (EPRFs) to cover the foreign exchange component of exportoriented enterprises. EPRFs are a kind of selective import support mechanism. In addition, they are a mechanism of rapid aid disbursement. In their attempts to diversify the SADCC economies, they can be compared with the second window of the Common Fund, on the agenda of the UNCTAD Conference of 1976 in Nairobi, and agreed upon in 1979, but never begun.

Linking of aid funds with commercial interests has been much criticised in the past. Many inquiries into the nature of development cooperation have revealed a correla- 
tion between aid and the foreign trade and investment interests of the donor countries, including their concern to guarantee the supply of raw materials. The newly established EPRFs involve a compromise between the profit motives of the enterprise sector (local and foreign), the moral obligations of aid institutions and the needs of the SADCC economies. Again, the effective implementation of such funding programmes requires careful attention to forward planning priorities. The SADCC member states will have to explain the range of items they propose to cover under their respective EPRF schemes.

Of course it is up to the SADCC to initiate discussions with cooperating partners on EPRF programmes. Some of the latter are already involved in this field, notably the Nordic countries who have recently agreed on the creation of the Norsad Fund, to provide forex loans to joint SADCC/Nordic ventures for the purchase of production inputs. With increasing emphasis now being placed by the SADCC on investment in production, the time may have come for Belgium also to consider re-aligning assistance in this new direction. 